Research Article

\title{
Exchange Rate Risk Analysis Based on Firm Data: A Global Value Chain Perspective
}

\author{
Mimi Ning $(\mathbb{D}$ and Jianhong Qi \\ Economics Department, Shandong University, Jinan, Shandong 250100, China \\ Correspondence should be addressed to Mimi Ning; mimi19830127@sina.com
}

Received 25 March 2020; Revised 24 May 2020; Accepted 29 June 2020; Published 21 July 2020

Academic Editor: Ewa Pawluszewicz

Copyright ( 2020 Mimi Ning and Jianhong Qi. This is an open access article distributed under the Creative Commons Attribution License, which permits unrestricted use, distribution, and reproduction in any medium, provided the original work is properly cited.

\begin{abstract}
This paper investigates whether firms' participation in the global value chain (GVC) weakens the exchange rate risk and its mechanism. Based on Powers and Riker's (2013) expanding exchange rate risk model, this paper matches data from China's refined input-output table, the customs database, and the industrial enterprise database from 2002 to 2009 to measure the firms' GVC forward linkages and backward linkages and therefore empirically tests the relationship between participation in the GVC and the exchange rate risk. The results show that participation in the GVC reduces firms' exchange rate risk through a "comovement effect" for forward linkages and a "hedging effect" for backward linkages; differences in a firm's position in the GVC affect the extent of reduction in the exchange rate risk. Encouraging firms to participate in the GVC and strengthening GVC relationship with high-income countries in particular play an important role in minimizing the exchange rate risk.
\end{abstract}

\section{Introduction}

In recent years, it has been debated whether the exchange rate risk has been weakened [1]. Under traditional trade theory, the exchange rate risk is transferred to the domestic production process completely and results in a change in exports. However, the impact of the exchange rate risk becomes more complex when a country's exports are used as intermediates in another country in the global value chain (GVC) network. It is worth further investigating whether the GVC network reduces the exchange rate risk. In recent years, many countries have joined the GVC network. Johnson and Noguera [2] give a clearer picture of global value-added activity: since 1970, most countries' foreign value-added in exports has been increasing and foreign value-added accounts for $20-25 \%$ of global exports, and this share is higher for specific products (such as electronics) or specific countries (such as Mexico or China). Chinese GVC trade has developed rapidly after its entry into the World Trade Organization (WTO), while it has also experienced frequent fluctuations in the renminbi (RMB) exchange rate, so it is practically significant to investigate the relationship between participation in the GVC and the exchange rate risk.

Previous studies have assumed that the exporter's total marginal cost was in the exporter's domestic currency. However, if intermediate inputs are imported from other countries and these costs are not denominated in the exporter's domestic currency, the exporter's marginal cost will only be influenced by fluctuations in the domestic currency partially. This implies that the intermediate trade has a weakening effect on exchange rate risks [3]. When considering the GVC network, both the currency impact of import countries and export countries need to be accounted for. For example, the appreciation of the RMB will increase Chinese exporters' marginal cost depending on the share of domestic inputs in exports, and it will also increase the marginal cost of exporters who use Chinese products as intermediate inputs. Thus, the GVC presents a new context to find reasons for the weakening exchange rate risk.

Much of the literature on the relationship between the GVC and exchange rate risk focuses on the production process which is divided into inputs and outputs. From the 
input perspective, participating in the GVC will weaken the exchange rate risk through the "hedging effect"; if the GVC network is different from whole-process domestic manufacturing, the exchange rate risk will impact both imported and exported intermediate products at the same time, thus resulting in a risk hedging effect which weakens the exchange rate risk [4]. Ahmed [5] found that if the domestic currency is appreciating (depreciating), export prices will increase (decrease). At the same time, if the price of imported intermediate inputs decreases (increases), the exporter can withstand appreciation (depreciation) by partially offset changes, as a result of the reducing exchange rate risk. Greenway, Mahabir, and Milner [6], Berman, Martin, and Mayer [7], and Fauceglia et al. [8] used British, French, and Swiss firm data, respectively, and the results confirm the above view. From the output perspective, participating in the GVC will weaken the exchange rate risk through the "comovement effect"; as opposed to the traditional trade model that regards all exported products as final consumer goods, the GVC network divides exported products into final products and intermediate products [9]. Some studies suggested that ignoring the GVC mode of production and export composition, and instead directly considering all exports as final products, may lead to a distorted estimation of exchange rate risks [10].

Although some studies have explored this issue and have confirmed that participating in the GVC will weaken the exchange rate risk, these studies still fail to fully explain the role of the GVC. Studies have considered the role of the GVC "hedging effect" and "comovement effect" in weakening exchange rate risk, but when products are exported to a third country, the GVC "comovement effect" is not only related to the share of intermediate exports in the third country, but also related to the third country's export market distribution after processing. Existing research lacks analysis that tracks the flow of exports of the third country after processing. Similarly, existing research on the GVC "hedging effect" also fails to track the flow of inputs to the third country proceeding the direct intermediate input country, and so it fails to comprehensively and accurately assess the exchange rate risk. To comprehensively study the relationship between firms' participation in the GVC and exchange rate risk, these issues are worth further investigation.

Compared to the existing literature, this study has three main contributions which may shed light on further studies. Firstly, the study extends the exchange rate risk model used by Powers and Riker's [11], using upstreamness and downstreamness [12], to track the forward and backward linkages of trade flows and expand the model to model the exchange rate risk within the GVC. Secondly, this study uses the Cobb-Douglas utility function to replace the constant elasticity of substitution utility function in Powers and Riker's [11] original model, thus establishing a new theoretical framework. This replacement is made to ensure that the model is an appropriate one for the Chinese context. Chinese firms are primarily distributed towards the middle and low ends of the GVC. Generally, intermediate products imported are technology-intensive products at the top of the GVC. At the same time, by changing the utility function used in the original model, the applicable scope of the theory is broadened. Thirdly, as opposed to previous research which has used country-level data, this study has used data at the firm and country levels, which can better reveal the relationship between participating in the GVC and the exchange rate risk.

\section{Theoretical Framework and Hypotheses}

The theoretical analysis framework used in this study is an extension of Powers and Riker's [11] exchange rate risk model. The framework is made up of four parts. The first two are from the original model, except for the replacement of the utility function, and the third and fourth parts are new extensions: part one analyzes the "hedging effect" from a backward linkage perspective and studies how the exchange rate risk affects the marginal cost through intermediate input imports and how this then affects the export price; part two analyzes the "comovement effect" from a forward linkage perspective, and combined with the first part, it studies how the exchange rate risk affects the markup through intermediate exports and how this then affects the export price; part three builds the link between the "hedging effect" and the GVC position, and the "comovement effect" and the GVC position; and part four builds the new exchange rate risk model with firms' positions in the GVC.

2.1. "Hedging Effect" in GVCBackward Linkages. Suppose the world economy consists of many countries $(i, j$, and $k n)$. In each country, there is only one firm that produces only one product for export, $s$, which can be used as both an intermediate and a final product. The total output of country $j$ is composed of the domestic added value $\left(X_{j t}\right)$ and the intermediate input $\left(V_{j t}\right)$ (which includes domestic intermediate inputs $\left[V_{j j t}\right]$ and imported intermediate inputs $\left.\left[V_{i j t}\right]\right)$. $a$ is the imported intermediate input share of total inputs from country $i$ by country $j\left(a=\sum_{1}^{N} a_{i}\right) ; b$ is the domestic intermediate input share of total inputs; and $a+b=1$. The Cobb-Douglas utility function for consumers in country $j$ for good $s$ is as follows:

$$
U\left(V_{i j t}, V_{j j t}\right)=\left(V_{i j t}\right)^{a}\left(V_{j j t}\right)^{b} .
$$

After log transforming equation (1), it reads as follows:

$$
\ln U\left(V_{i j t}, V_{j j t}\right)=a \ln \left(V_{i j t}\right)+b \ln \left(V_{j j t}\right) \text {. }
$$

According to microeconomic theory, under certain budget constraints, when the marginal rate of substitution for two goods is equal to the relative price of the goods, the optimal equilibrium condition of imported intermediates is obtained by combining equation (1) as follows:

$$
\mathrm{MRS}=\frac{\mathrm{MU}_{i j t}}{\mathrm{MU}_{j j t}}=\frac{a}{b}\left(\frac{V_{j j t}}{V_{i j t}}\right)=\frac{p_{i j t}}{p_{j j t}},
$$

where $p_{i j t}$ is the price of good $s$ exported from country $i$ to country $j$ in year $t$ (expressed in the currency of country $j$ ), that is, $p_{i j t}=\left(p_{i i t} / E_{i j t}\right)$, in which $p_{i i t}$ is the domestic price of export good $s$ in country $i$ and $E_{i j t}$ is the nominal exchange 
rate between country $i$ and country $j$ in year $t$ under the indirect method of quotation (if $E_{i j t}$ is rising, the currency of country $i$ depreciates against the currency of country $j$ ); $p_{j j t}$ is the price of local good $s$ in country $j$. From equation (3), we can get the expression of the relative demand of consumers in country $j$ for good $s$ :

$$
\frac{V_{i j t}}{V_{j j t}}=\left(\frac{b}{a}\right)\left(\frac{p_{i j t}}{p_{j j t}}\right)^{-1} .
$$

After $\log$ differentiating equation (4), the following equation is obtained:

$$
\widehat{v_{i j t}}-\widehat{v_{j j t}}=(-1)\left[\widehat{p_{i j t}}-t \widehat{p_{j j t}}\right] .
$$

We assume that the proportion of domestic and foreign intermediate inputs does not change with time over a long period. The cost of export good $s$ in country $i$ also includes the intermediate input import from country $k$ along with the corresponding currency exposure, where $p_{i i t}$ is the raw material price in the domestic currency of country $i$ used for production, $p_{k k t}$ is the price of imported intermediates denominated in the currency of country $k, E_{k j t}$ is the bilateral nominal exchange rate between country $k$ and country $j$ in year $t$, and $\lambda$ is the exchange rate pass-through (ERPT). We can derive the expression for the price of the exports of good $s$ from country $i$ to country $j$ :

$$
\widehat{p_{i j t}}=\lambda\left[\sum_{k} \theta_{k i t}\left(\widehat{p_{k k t}}-t \widehat{E_{k j t}}\right)+\theta_{i i t}\left(\widehat{p_{i i t}}-t \widehat{E_{i j t}}\right)\right],
$$

where the variable $\theta_{k i t}$ represents the cost share of country $k$ for export good $s$ from country $i$ in year $t$ and reflects the backward linkage in the GVC between country $i$ and country $k$ in year $t ; \sum_{k} \theta_{k i t}$ is the foreign value-added share of good $s$ in country $i ; \theta_{i i t}$ is the domestic value-added share of country $i$, and therefore $\sum_{k} \theta_{k i t}+\theta_{i i t}=1$. Substituting equations (6) into (5) gives the expression for country $i$ 's exports of good $s$ :

$$
\widehat{v_{i j t}}-\widehat{v_{j j t}}=\widehat{p_{j j t}}-\lambda\left[\sum_{k} \theta_{k i t}\left(\widehat{p_{k k t}}-t \widehat{E_{k j t}}\right)+\theta_{i i t}\left(\widehat{p_{i i t}}-t \widehat{E_{i j t}}\right)\right] \text {. }
$$

Given that the backward linkage in the GVC $\sum_{k} \theta_{k i t}\left(\widehat{p_{k k t}}-t \widehat{E_{k j t}}\right)$ includes the "hedging effect" of currency exposure, the previous theory ignored the GVC factor and assumed that the production of exports only uses domestic components (i.e., $\sum_{k} \theta_{k i t}=0, \theta_{i i t}=1$ ). Equations (6) and (7) are read as follows when the GVC is ignored:

$$
\begin{aligned}
\widehat{p_{i j t}} & =\lambda\left(\widehat{p_{i i t}}-t \widehat{E_{i j t}}\right), \\
\widehat{v_{i j t}}-\widehat{v_{j j t}} & =\widehat{p_{j j t}}-\lambda\left(\widehat{p_{i i t}}-t \widehat{E_{i j t}}\right) .
\end{aligned}
$$

Therefore, it is speculated that exporter firms in the GVC are less motivated to the shift exchange rate risk pressure, and they must have a higher ERPT to achieve the same $\widehat{p_{i j t}}$. Thus, ignoring GVC linkages may overestimate the exchange rate risk. Therefore, the following hypothesis is obtained.
Hypothesis 1. The "hedging effect" in GVC backward linkages reduces firms' exchange rate risk.

2.2. "Comovement Effect" in GVC Forward Linkages. The variable $Y_{j t}$ represents the total consumption expenditure of good $s$ in country $j$ and $p_{j t}$ represents the consumer price index in country $j$. Under the Cobb-Douglas utility function in equation (1), we can rewrite the relative demand expression in equation (4) as the following Marshallian demand (in microeconomics, a consumer's Marshallian demand function specifies what the consumer would buy for every price and income or wealth combination, assuming it perfectly solves the utility maximization problem) function:

$$
V_{i j t}=Y_{j t}\left(p_{j t}\right)\left(p_{i j t}\right)^{-1},
$$

where $V_{i j t}$ represents the exports from country $i$ to country $j$ in year $t$ and $p_{j t}=\sum_{k} \gamma_{k j t} p_{k j t}$ represents the weighted average price of intermediate good $s$ imported from country $j$, in which $\gamma_{k j t}$ is the consumption share of country $k$ 's exports in country $j$. After log differentiating equation (10), the following equation is obtained:

$$
\widehat{v_{i j t}}=\widehat{y_{j t}}+\left(\widehat{p_{i t}}-t \widehat{p_{i j t}}\right) \text {. }
$$

Assuming that the production of good $s$ in country $k$ requires the use of intermediate good $s$ imported from country $i$ and other countries, equation (6) can be used to obtain the following equation:

$$
\begin{aligned}
\widehat{p_{k j t}}= & \lambda\left[\theta_{i k t}\left(\widehat{p_{i i t}}-t \widehat{E_{k j t}}\right)+\sum_{f} \theta_{f k t}\left(\widehat{p_{f f t}}-t \widehat{E_{f j t}}\right)\right. \\
& \left.+\theta_{k k t}\left(\widehat{p_{k k t}}-t \widehat{E_{k j t}}\right)\right]
\end{aligned}
$$

where $\theta_{i k t}$ is the cost share of imports from country $k$ in country $j$ in year $t$, reflecting the degree of forward linkages between country $i$ and country $k$. Substituting equations (6) and (12) and $p_{j t}$ expression into equation (11), we can examine the influence of the exchange rate risk of country $i$ in year $t$, assuming all other economic variables remain unchanged except for $\widehat{E_{i j t}}$. The following equation expresses the relationship between the exchange rate risk and exports:

$$
\widehat{v_{i j t}}=(-1)\left(\lambda \sum_{k} \theta_{i k t} \gamma_{k j t} \widehat{E_{i j t}}-\lambda \theta_{i i t} \widehat{E_{i j t}}\right) .
$$

Trade elasticity $\left(\mathrm{TE}_{i j t}\right)$ is a measure of how responsive exports are to changes in exchange rates. It is often measured as the percentage change in exports, resulting from a one percent change in the exchange rate between the exporting and importing countries; in international trade theory, trade elasticity $\left.\left(\mathrm{TE}_{i j t}\right)\right)$ usually measures the impact of the exchange rate volatility risk on exports, thus indicating the degree of the exchange rate risk faced by firms. According to the definition of trade elasticity and equation (13), the trade elasticity $\left(\mathrm{TE}_{i j t}\right)$ of firms exporting from country $i$ to country $j$ is as follows: 


$$
\mathrm{TE}_{\mathrm{ijt}}=\frac{d \widehat{v_{i j t}}}{d \widehat{E_{i j t}}}=\underbrace{\lambda\left(\theta_{i i t}\right)}_{\text {self-price effect }}+\underbrace{(-1) \lambda \sum_{k} \theta_{i k t} \gamma_{k j t}}_{\text {price index effect }} .
$$

In the theoretical framework presented by Powers and Riker [11], the exchange rate risk model also uses trade elasticity $\left(\mathrm{TE}_{i j t}\right)$ to measure the degree of the exchange rate risk faced by firms. As shown in equation (14), it can be divided into two parts: the self-price effect and the price index effect. The self-price effect studies the impact of the exchange rate risk on the domestic added value and uses the share of the domestic added value. If the export is made up of more foreign added values (and less domestic added values), the "hedging effect" of currency exposure will weaken the exchange rate risk, as exchange rate risk only affects the domestic added value. The price index effect examines the impact of the exchange rate on countries which use intermediate goods from country $i$. The upstream and downstream comovement will also reduce the exchange rate risk. Assuming that other economic variables do not change, the self-price effect is usually positive, and the exchange rate risk tends to weaken with deepening GVC backward linkages GVC (i.e., $\theta_{i i t}$ declines); the price index effect is usually negative, which plays a buffer role in the exchange rate risk, and its influence tends to strengthen the deepening of GVC forward linkages (i.e., $\sum_{k} \theta_{i k t} \gamma_{k j t}$ rises). Therefore, the following hypothesis is obtained.

Hypothesis 2. The "comovement effect" in GVC forward linkages reduces firms' exchange rate risk.

\subsection{GVC Forward and Backward Linkages considering a} Firm's GVC Position. In the original model, GVC backward linkage $\left(\theta_{i i t}\right)$ mainly focuses on the share of the domestic added value in the total added value; GVC forward linkage $\left(\sum_{k} \theta_{i k t} \gamma_{k j t}\right)$ only emphasizes the share of intermediate exports in total exports. The forward and backward linkages in the original model only focus on the initial decomposition of the GVC trade flow and do not pay attention to decomposition of the whole GVC process. For example, GVC backward linkages distinguish between the share of the domestic added value and the foreign added value but do not further distinguish whether the foreign added value is derived directly from the importing country or if it is derived from other countries in the GVC. Similarly, GVC forward linkages just distinguish between intermediate and final goods that are exported and do not further distinguish whether the intermediate exports are directly consumed by the importing country, or processed and then exported to a third country as new intermediates, and they do not consider the trade flow of the third country. The original model does not pay sufficient attention to the overall GVC flow. Some research notes this shortcoming, but does not solve it due to the complexity of flow tracking. This paper contributes to the literature by attempting to address this shortcoming. This paper uses the concept of downstreamness instead of GVC backward linkages $\left(\theta_{i i t}\right)$ and similarly uses upstreamness instead of GVC forward linkages $\left(\sum_{k} \theta_{i k t} \gamma_{k j t}\right)$. Upstreamness not only distinguishes between final goods and intermediates but also expresses the GVC length. Similarly, downstreamness distinguishes between the share of domestic inputs and foreign inputs and also contains information about the whole GVC trade flow.

What follows is a discussion of the specific relationship between forward linkages and upstreamness and backward linkages and downstreamness. We start with an inputoutput model as a basic framework:

$$
\begin{gathered}
Y_{i}=\sum_{s=1}^{S} \sum_{j=1}^{J} Z_{i j}+F_{i}, \\
Y_{j}=\sum_{r=1}^{S} \sum_{i=1}^{J} Z_{i j}+\mathrm{VA}_{j} .
\end{gathered}
$$

Equation (15) is a decomposition from the output perspective of the input-output model, which is also known as the forward linkage in the GVC. $Y_{i}$ represents the total output of industry $i ; Z_{i j}$ represents the input-output matrix of intermediates; and $F_{i}$ represents the final goods in the output of industry $i$. Equation (16) is a decomposition from the input perspective of the input-output model, which is also known as the backward linkage in GVC. $Y j$ represents the total input of industry $j$, and $\mathrm{VA}_{j}$ represents the domestic added value of industry $j$.

According to Antràs and Chor [12], the expressions for simple upstreamness (only distinguishes between final goods and intermediate goods) and simple downstreamness (only distinguishes between domestic inputs and foreign intermediate inputs) are as follows:

$$
\begin{gathered}
\frac{F}{\mathrm{GO}}=\frac{F}{Y_{i}}, \\
\frac{\mathrm{VA}}{\mathrm{GO}}=\frac{\mathrm{VA}_{\mathrm{j}}}{Y_{j}},
\end{gathered}
$$

where $(F / G O)$ is the share of final goods, and so $(1-F / G O)$ is the share of intermediates, which is equal to the forward linkage $\sum_{k} \theta_{i k t} \gamma_{k j t}$ in the original model; (VA/GO) is the share of domestic value-added, which is equal to the backward linkage $\left(\theta_{i i t}\right)$ in the original model.

The intermediate input matrix $\left(Z_{i j}\right)$ can be further decomposed to incorporate the GVC length. The expressions of upstreamness and downstreamness proposed by Antràs and Chor [12] are as follows.

From the output perspective, the first term on the righthand side of equation (19) indicates that the distance between the intermediate inputs and the final goods is one step, the second term indicates that the distance is two steps ( $i$ is used to produce $k$, and then $k$ is used to produce final good $j$ ), and so on. In other words, industry i's output can be used directly as a final good, or as an intermediate input at different positions and distances from the good's final use. Therefore, the average position can be calculated as the weighted sum of the distances plus one, where the weights are the ratio of the output used as intermediate inputs in the respective positions to the total value of the output. This is 
the expression for upstreamness. The bigger the $U_{i}$ is, the further upstream the industry is in terms of its contribution to production chains:

$$
\begin{aligned}
U_{i}= & 1 \times\left(\frac{F_{j}}{Y_{i}}\right)+2 \times\left(\frac{\sum_{s=1}^{S} \sum_{j=1}^{J} d_{i j} F_{j}}{Y_{i}}\right) \\
& +3 \times\left(\frac{\sum_{s=1}^{S} \sum_{j=1}^{J} \sum_{t=1}^{S} \sum_{k=1}^{J} d_{i j} d_{j k} F_{k}}{Y_{i}}\right)+\cdots
\end{aligned}
$$

From the input perspective, the number of production stages is defined as the distance according to whether the production link is close to the initial domestic factor input. Based on the above ideas, the added value of domestic input factors is defined as distance one, the distance of using the added value of intermediates for the direct importing country is two, and so on. Once again, we take the distance as the weight and sum the proportion of the added value of intermediates in each stage to get equation (20), which is the expression for downstreamness:

$$
\begin{aligned}
D_{i}= & 1 \times\left(\frac{V A_{j}}{Y_{i}}\right)+2 \times\left(\frac{\sum_{r=1}^{S} \sum_{i=1}^{J} b_{i j} V A_{i}}{Y_{i}}\right) \\
& +3 \times\left(\frac{\sum_{r=1}^{S} \sum_{i=1}^{J} \sum_{t=1}^{S} \sum_{k=1}^{J} b_{k i} b_{i j} V A_{k}}{Y_{i}}\right)+\cdots
\end{aligned}
$$

Upstreamness and downstreamness can be calculated using these equations. The mathematical expression indicates that high upstreamness means that the proportion of intermediate exports is high in the original model; similarly, high downstreamness means that the proportion of the added value outside China is high in the original model. Furthermore, according to Chor, Manova, and Yu [13], the upstreamness and downstreamness of the industry are refined to the level of the firm. The final expression used to calculate firm upstreamness is as follows:

$$
\text { firmup }_{i t}=\sum_{i=1}^{N}\left(\frac{X_{i i t}}{X_{i t}}\right) U_{i t},
$$

where firmup ${ }_{i t}$ indicates the upstreamness of firm $i$ in year $t$; $X_{i t}$ is the quantity of the firm's total exports; $X_{i i t}$ is the quantity of the firm's exports in industry $i$; the weight $\left(X_{i i t} / X_{i t}\right)$ reflects the importance of industry $i$ for the firm. The expression used to calculate firm downstreamness is

$$
\text { firmup }_{i t}=\sum_{j=1}^{N}\left(\frac{X_{i j t}}{X_{i t}}\right) D_{j t}
$$

where firmdown ${ }_{i t}$ indicates the downstreamness of firm $i$ in year $t ; X_{i t}$ is the quantity of the firm's total exports; $X_{i j t}$ is the quantity of the firm's exports in industry $j$; the weight $\left(X_{i j t} / X_{i t}\right)$ reflects the importance of industry $j$ for the firm.

2.4. Exchange Rate Risk and Firms' GVC Position. According to the above analysis, we can take upstreamness as a measure of the forward linkage and downstreamness as a measure of the backward linkage and incorporate these expressions into the equation for trade elasticity in the original model:

$$
\mathrm{TE}_{i j t}=\underbrace{\lambda_{j}\left(\frac{1}{\text { firmdown }_{i t}}\right)}_{\text {self-price effect }}+\underbrace{(-1) \lambda_{j}\left(\frac{1-1}{\text { firmup }_{i t}}\right)}_{\text {price index effect }} .
$$

Equation (23) shows that when the firm's downstreamness ( firmdown $_{i t} \geq 1$ ) is equal to 1 , all added values are domestic. The larger the downstreamness, the greater the share of foreign intermediates and the greater the "hedging effect"; the self-price effect is positive and tends to weaken with increase in downstreamness. When the firm's upstreamness ( firmup $_{i t} \geq 1$ ) is equal to 1 , exports are only made up of final goods and the price index effect is 0 , which also means that the "comovement effect" caused by the forward linkage in the GVC is 0 . The larger the upstreamness, the greater the share of export intermediates and the greater the "comovement effect"; the more negative the price index effect, the greater the buffer effect on the exchange rate risk. The influence of the price index effect tends to increase as upstreamness increases. This is consistent with the effects of the forward linkage and the backward linkage in the original model. At the same time, a higher upstreamness of a firm indicates a higher position in the GVC from the output perspective; a higher downstreamness of a firm represents a lower position in the GVC from the input perspective. Therefore, after participating in the GVC, firms weaken the exchange rate risks through forward linkages and backward linkages simultaneously, and the degree to which exchange rate risks are weakened is related to the firms' GVC position. Based on the above analysis, the third hypothesis is put forward.

Hypothesis 3. The higher a firms' upstreamness, the greater the "comovement effect"; while the greater a firms' downstreamness, the greater the "hedging effect"; both effects work to weaken the exchange rate risk simultaneously.

\section{Data Source, Variable Selection, and Typified Factual Description}

3.1. Data Source, Matching, and Sorting. This paper matches data from China's input-output table obtained from the National Bureau of Statistics of China, the customs database from China's general administration of customs, and the industrial enterprise database from the National Bureau of Statistics of China. The study uses three-dimensional panel data, with the dimensions being firm, country, and year. The panel data contain information on the exports of 106,420 Chinese firms to every country between 2002 and 2009. Finally, 2,562,428 firm-country-year sample data were obtained by matching the three databases.

Firstly, the input-output table is sorted. The input-output tables of 122 sectors in 2002 and 135 sectors in 2007 are used. Due to statistical inconsistencies between China's departments in 2002 and 2007, this paper takes the 2002 input- 
output table to be the industry benchmark and summarizes the industries after industry segmentation in 2007 according to the industries in 2002. Secondly, based on Upward, Wang, and Zheng [14] study, the industrial enterprise database and the customs database are combined. Finally, China's input-output table is matched with these two merged databases. It should be noted that the inputoutput table of China's segmented industries is prepared once every five years, and in the years that it is not prepared, it is necessary to further investigate the input-output relationship. In this paper, the differential smoothing method is used to work with the data.

\subsection{Variable Selection}

3.2.1. Dependent Variable. Exports ( $V)$ : data on firm exports are acquired from the customs database. Due to the volatility of the data, the logarithmic form is used for smooth processing.

\subsubsection{Independent Variables}

(i) The bilateral real exchange rate (RER): in this paper, data on the bilateral real exchange rate are used, and the expression used to calculate this is as follows:

$$
\operatorname{RER}_{j t}=\operatorname{ner}_{j t} \times \frac{\mathrm{cpi}_{j t}}{\mathrm{cpi}_{\text {chnt }}},
$$

where ner $_{j t}$ is the bilateral nominal exchange rate between China and country $j$ in year $t$; $\operatorname{cpi}_{j t}$ is the consumer price index (CPI) of country $j$ in the

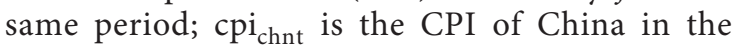
same period. The original data on bilateral nominal exchange rates and the CPI are from the International Monetary Fund (IMF), and the CPI is converted using 2010 as the base year. The logarithmic form is also used for smooth processing.

(ii) GVC forward linkage $(F)$ and backward linkage $(B)$ : this paper uses the upstreamness $\left(\right.$ firmup $_{i t}$ ) and downstreamness $\left(\right.$ firmdown $\left._{i t}\right)$ calculated by the method used by Antràs and Chor [12] for measurement. The logarithmic difference form is used to process the data. The calculation method is shown above.

\subsubsection{Control Variables}

(i) Firm total factor productivity (TFP): from the perspective of enterprise heterogeneity, total factor productivity (TFP) is introduced as a control variable and is estimated by referring to the Olley-Pakes method [15], which is in logarithmic form.

(ii) Firm profit rate (profitr): the ratio of the firm profit to the firm output value is a control variable and is processed using the logarithmic form. Data on this were acquired from the Chinese industrial enterprise database.

(iii) Firm research and development (R\&D): firm investment in research and development is a control variable and was processed using the logarithmic form. Data on this were acquired from the Chinese industrial enterprise database.

Based on this, the statistical description and correlation matrix of the above variables are shown in Tables 1 and 2 .

\subsection{Typified Factual Description}

3.3.1. Forward Linkages of Chinese Firms in the GVC. In this paper, firms' upstreamness is used to measure GVC forward linkages. Figure 1 shows the kernel density diagrams of GVC forward linkages from 2002 to 2009, which illustrates that the forward linkages of Chinese firms in the GVC follows a normal distribution and there is not an obvious difference from these distributions for the annual distribution.

3.3.2. Backward Linkages of Chinese Firms in the GVC. In this paper, a firm's downstreamness is used to measure GVC backward linkages. Figure 2 shows the kernel density diagrams of GVC backward linkages from 2002 to 2009, which illustrates that forward linkages of Chinese firms in the GVC follow a normal distribution. The annual distribution, however, is significantly different, which indicates that the backward linkages between firms are significantly different. Therefore, ignoring GVC backward linkages will distort the estimated firm's exchange rate risk.

3.3.3. Correlation between GVC Forward Linkages and Exchange Rate Risk and GVC Backward Linkages and Exchange Rate Risk. In this paper, trade elasticity is used to measure the exchange rate risks faced by firms. The greater the trade elasticity [16] is, the more sensitive exports are to exchange rate fluctuations. Table 3 shows that there is an obvious negative correlation between GVC forward linkages and the exchange rate risk. The correlation coefficient between GVC forward linkages and the exchange rate risk is -0.010 , and the correlation coefficient between GVC backward linkages and the exchange rate risk is -0.005 . This shows that firms' participation in the GVC can reduce the exchange rate risk through GVC forward and backward linkages. Figure 3 shows the relationship between GVC forward linkages and GVC backward linkages with exchange rate risk. With the increase in GVC forward and backward linkages, the exchange rate risk faced by firms follows a downward trend. This typical fact provides a practical basis for the three assumptions in the theoretical framework of this paper and provides a preliminary judgment on the relationship between GVC forward and backward linkages and exchange rate risk. 
TABLE 1: Descriptive statistics of variables.

\begin{tabular}{|c|c|c|c|c|c|c|c|}
\hline Variable & Number & Mean & Variance & Maximum & Minimum & Skewness & Kurtosis \\
\hline Exports $(\ln V)$ & $2,562,428$ & 6.30 & 2.22 & 18.10 & -4.58 & -0.06 & 3.64 \\
\hline Bilateral real exchange rate (ln RER) & $2,882,375$ & 0.30 & 2.45 & 3.22 & -8.58 & -1.41 & 4.29 \\
\hline GVC forward linkage $(\Delta \ln F)$ & $1,346,367$ & -0.05 & 0.12 & 1.20 & -1.19 & -0.39 & 17.81 \\
\hline GVC backward linkage $(\Delta \ln B)$ & $1,346,367$ & 0.02 & 0.06 & 0.40 & -0.36 & 1.82 & 6.26 \\
\hline Firm total factor productivity $(\ln T F P)$ & $2,883,486$ & 2.30 & 0.32 & 10.81 & -6.68 & 2.33 & 42.12 \\
\hline Firm research and development (ln R\&D) & 283,032 & 5.88 & 1.52 & 7.08 & 0.00 & -1.30 & 4.08 \\
\hline Firm profit rate (ln profitr) & $2,882,810$ & 0.13 & 0.28 & 2.20 & -0.40 & 3.84 & 24.85 \\
\hline
\end{tabular}

TABLE 2: Correlation coefficient matrix of variables.

\begin{tabular}{|c|c|c|c|c|c|c|c|}
\hline & $\begin{array}{l}\text { Exports } \\
(\ln V)\end{array}$ & $\begin{array}{l}\text { Bilateral real } \\
\text { exchange rate } \\
\text { (ln RER) }\end{array}$ & $\begin{array}{l}\text { GVC } \\
\text { forward } \\
\text { linkage } \\
(\Delta \ln F) \\
\end{array}$ & $\begin{array}{c}\text { GVC } \\
\text { backward } \\
\text { linkage } \\
(\Delta \ln B)\end{array}$ & $\begin{array}{c}\text { Firm total factor } \\
\text { productivity } \\
(\ln \text { TFP })\end{array}$ & $\begin{array}{l}\text { Firm research and } \\
\text { development } \\
(\ln R \& D)\end{array}$ & $\begin{array}{l}\text { Firm profit } \\
\text { rate } \\
\text { (ln profitr) }\end{array}$ \\
\hline Exports $(\ln V)$ & 1.00 & & & & & & \\
\hline $\begin{array}{l}\text { Bilateral real } \\
\text { exchange rate } \\
\text { (ln RER) }\end{array}$ & 0.03 & 1.00 & & & & & \\
\hline $\begin{array}{l}\text { GVC forward } \\
\text { linkage }(\Delta \ln F)\end{array}$ & 0.00 & 0.02 & 1.00 & & & & \\
\hline $\begin{array}{l}\text { GVC backward } \\
\text { linkage }(\Delta \ln B)\end{array}$ & -0.01 & 0.01 & 0.28 & 1.00 & & & \\
\hline $\begin{array}{l}\text { Firm total factor } \\
\text { productivity } \\
(\ln \text { TFP) }\end{array}$ & 0.02 & 0.00 & -0.01 & 0.01 & 1.00 & & \\
\hline $\begin{array}{l}\text { Firm research and } \\
\text { development } \\
(\ln R \& D)\end{array}$ & 0.09 & -0.03 & 0.00 & -0.01 & 0.09 & 1.00 & \\
\hline $\begin{array}{l}\text { Firm profit rate } \\
\text { (ln profitr) }\end{array}$ & 0.01 & -0.01 & -0.03 & -0.01 & 0.11 & 0.06 & 1.00 \\
\hline
\end{tabular}

\section{Empirical Analysis and Discussion}

\subsection{Benchmark Regressions.}

$$
\begin{aligned}
\ln V_{i j t}= & \alpha+\left[\beta_{1}+\beta_{2} \Delta \ln F_{i t}+\beta_{3} \Delta \ln B_{i t}+\beta_{4} \Delta \ln \mathrm{TFP}_{\mathrm{it}}\right] \\
& \ln \mathrm{RER}_{j t}+\gamma C_{i t}+\varphi_{i j}+\eta_{t}+\varepsilon_{i j t},
\end{aligned}
$$

where the subscript $i$ refers to the firm, $j$ refers to the country of export destination, $t$ refers to the time, $F$ and $B$ represent the firm's upstreamness and downstreamness, respectively, and $C_{i t}$ is a control for characteristics at the firm-level that change with time, including profit rate and $\mathrm{R} \& \mathrm{D}$. To ensure that the results are sufficiently robust, a variable for the fixed effects of the firm destination level $\left(\varphi_{i j}\right)$ and a time fixed effect variable $\left(\eta_{t}\right)$ are added. The regression results with double fixed effects are shown in Table 4.

If the GVC is not considered, as is the case in the first column of Table 4, for a $10 \%$ appreciation in the domestic currency, the value of the firms' exports will decrease by $1.93 \%$.

In the second column of Table 4, only the influence of GVC forward linkages is considered, and the interaction term of forward linkages and the exchange rate is added as an independent variable. The results show that GVC forward linkages have a significant impact on the trade elasticity coefficient. For a $10 \%$ increase in the forward linkage, the trade elasticity coefficient will decrease by $0.13 \%$, which means the exchange rate risk faced by firms will decrease. Therefore, with the increase in forward linkages, the GVC "hedging effect" will continue to weaken firms' exchange rate risk.

In the third column of Table 4, only the influence of the GVC backward linkage is considered, and the interaction between GVC backward linkages and the exchange rate is added as an independent variable. The results show that GVC backward linkages have a significant impact on the trade elasticity coefficient. For a $10 \%$ increase in backward linkages, trade elasticity will decrease by $0.26 \%$, which means the exchange rate risk faced by firms will decrease. Therefore, with the increase in backward linkages, the GVC "comovement effect" will continue to weaken firms' exchange rate risk.

The fourth column of Table 4 considers the influence of both forward and backward linkages. The results show that both forward and GVC backward linkages have a significant negative influence on the trade elasticity, which means that as forward and backward linkages increase, exchange rate risk weakens. Therefore, participation in the GVC will indeed weaken the exchange rate risk through the joint effects of the "hedging effect" and the "comovement effect." The degree to which exchange rate risk weakens is related to the position of the firm in the GVC.

Many studies have pointed out that firm total factor productivity (TFP) plays a significant role in weakening the 


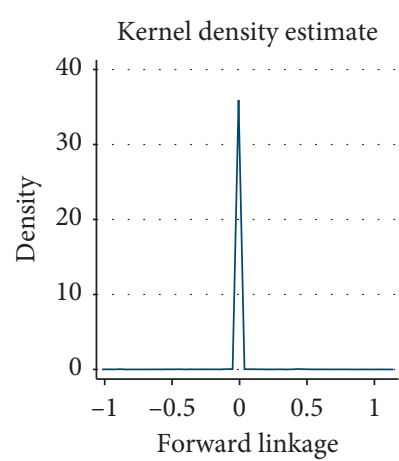

Kernel $=$ Epanechnikov, bandwidth $=0.0070$

(a)

Kernel density estimate

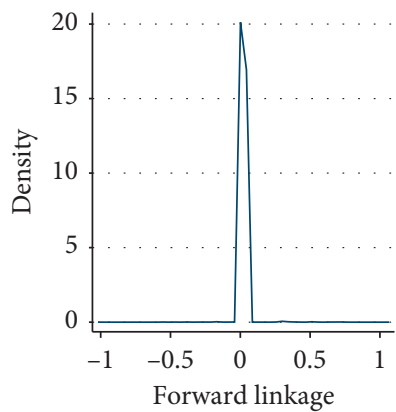

Kernel $=$ Epanechnikov, bandwidth $=0.0012$

(e)

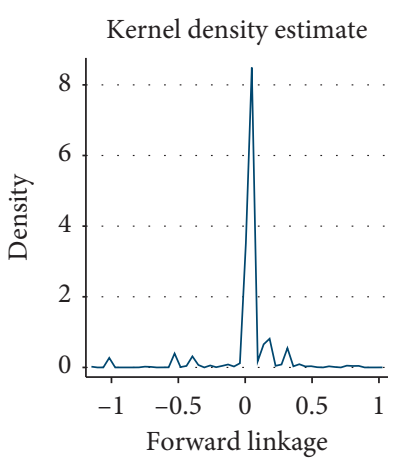

Kernel $=$ Epanechnikov, bandwidth $=0.0023$

(b)

Kernel density estimate

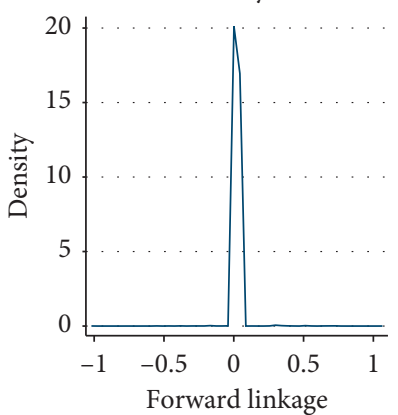

Kernel = Epanechnikov, bandwidth $=0.0012$

(f)

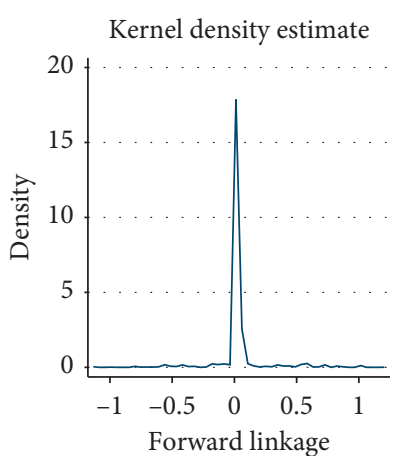

Kernel = Epanechnikov, bandwidth $=0.0031$

(c)

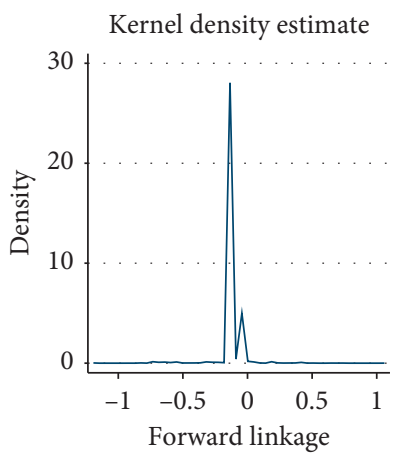

Kernel = Epanechnikov, bandwidth $=0.0020$

(g)

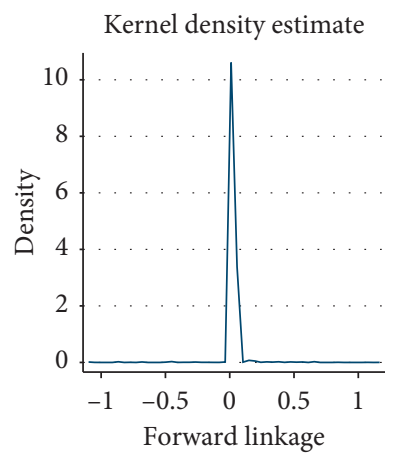

Kernel $=$ Epanechnikov, bandwidth $=0.0016$

(d)

Kernel density estimate

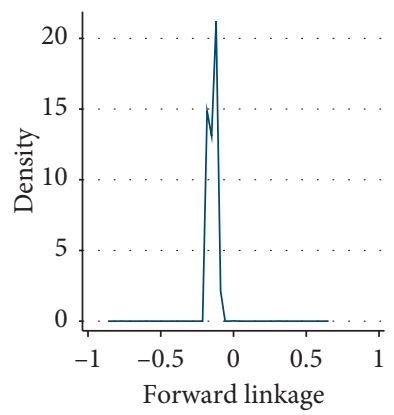

Kernel = Epanechnikov, bandwidth $=0.0022$

(h)

FIgUre 1: Kernel density diagrams of GVC forward linkages from 2002 to 2009.

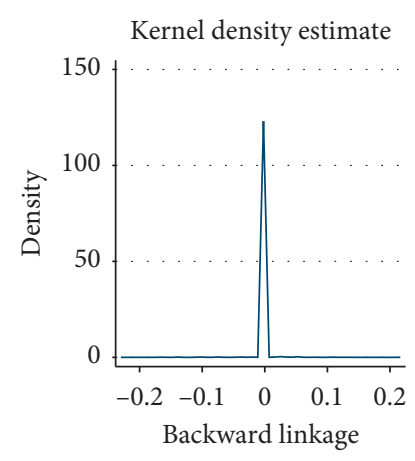

Kernel = Epanechnikov, bandwidth $=0.0013$

(a)

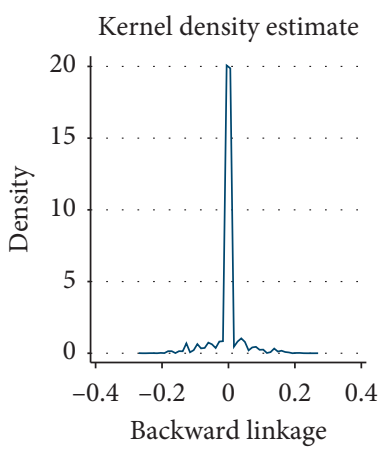

Kernel = Epanechnikov, bandwidth $=0.0027$

(b)

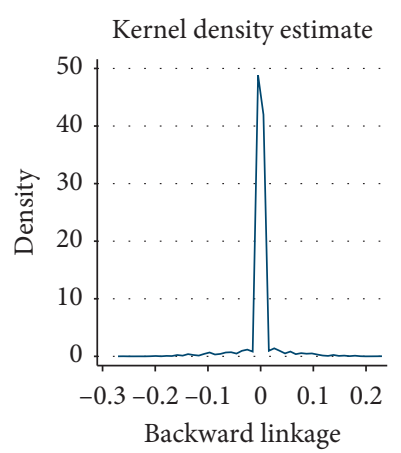

Kernel = Epanechnikov, bandwidth $=0.0034$

(c)

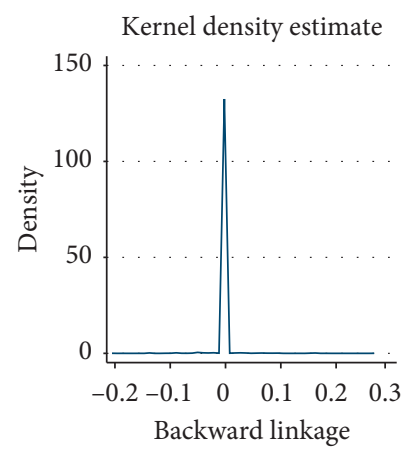

Kernel $=$ Epanechnikov, bandwidth $=0.0016$

Figure 2: Continued. 


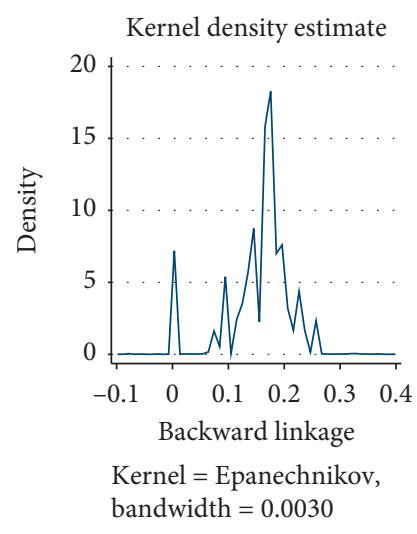

(e)

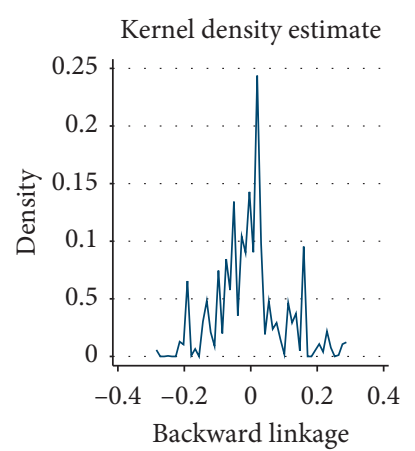

Kernel $=$ Epanechnikov, bandwidth $=0.0011$

(f)

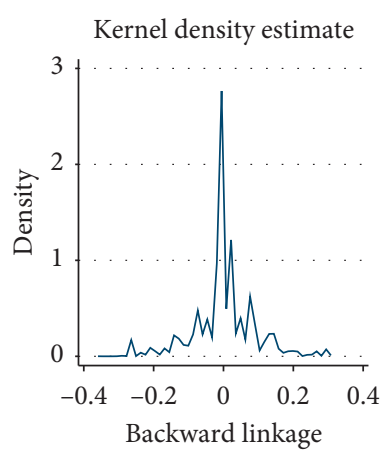

Kernel = Epanechnikov, bandwidth $=0.0024$

(g)

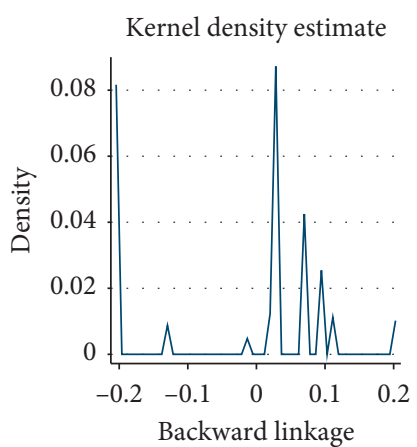

Kernel = Epanechnikov, bandwidth $=0.0002$

(h)

FIgure 2: Kernel density diagrams of GVC backward linkages from 2002 to 2009.

TABLe 3: Correlation coefficient matrix.

\begin{tabular}{lccc}
\hline & Exchange rate risk & Forward linkage & Backward linkage \\
\hline Exchange rate risk & 1.000 & & 1.000 \\
Forward linkage & -0.010 & 0.276 & 1.000 \\
Backward linkage & -0.005 & & \\
\hline
\end{tabular}

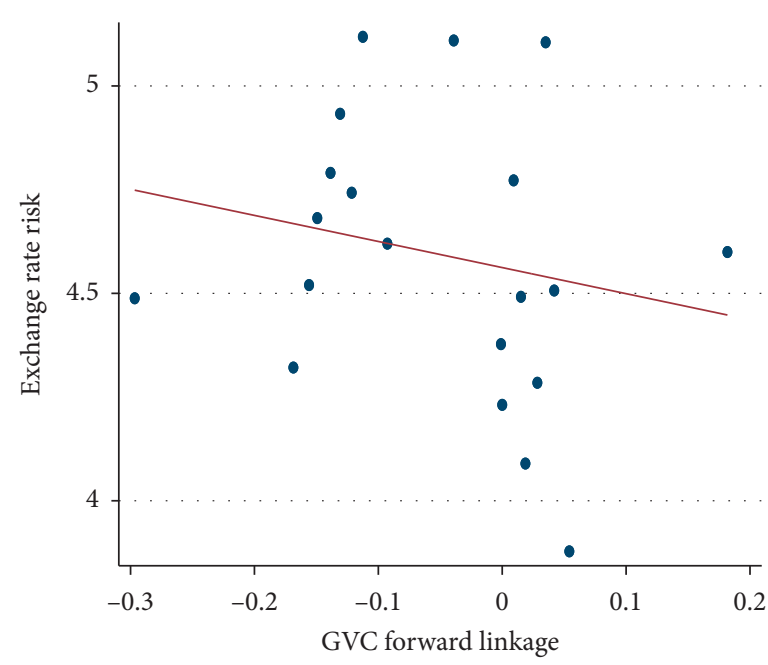

(a)

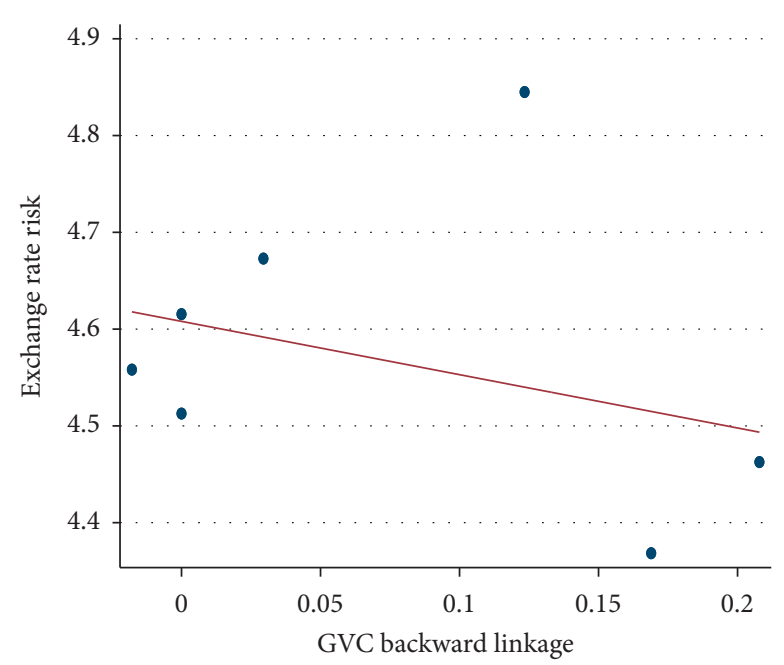

(b)

FIgURE 3: Scatter plots of forward linkage and backward linkage with exchange rate risk.

exchange rate risk [7, 17]. It is thus important to check whether the main conclusion of this paper still holds after controlling for the firm TFP channel. To test this, we introduce the interaction of TFP and the exchange rate in the regression model to see whether the regression coefficient of GVC forward and backward linkages is still significant. At the same time, we introduce the firm profit rate and $R \& D$ as control variables to test the robustness of the previous results.

The fifth column of Table 4 shows the influence of GVC forward linkages after controlling for the TFP channel and other control variables. The results show that the coefficient on the interaction of GVC forward linkages and trade elasticity is still significant and negative, which means that exchange rate risk decreases with increases in GVC forward linkages.

The sixth column of Table 4 shows the influence of GVC backward linkages after controlling for the TFP channel and other control variables. The results show that GVC backward linkages have a significant negative impact on trade elasticity, which means that exchange rate risk decreases with increases in GVC backward linkages.

The seventh column of Table 4 is the result of examining the influence of GVC forward linkages and backward 
TABLE 4: Forward linkage and backward linkage with exchange rate risk.

\begin{tabular}{|c|c|c|c|c|c|c|c|}
\hline & $V(1)$ & $V(2)$ & $V(3)$ & $V(4)$ & $V(5)$ & $V(6)$ & $V(7)$ \\
\hline$R E R$ & $\begin{array}{c}0.193^{* * *} \\
(9.67)\end{array}$ & $\begin{array}{c}0.291^{* * *} \\
(9.87)\end{array}$ & $\begin{array}{c}0.288^{* * *} \\
(9.72)\end{array}$ & $\begin{array}{c}0.294^{* * *} \\
(9.93)\end{array}$ & $\begin{array}{l}0.291^{*} \\
(1.76)\end{array}$ & $\begin{array}{l}0.323^{*} \\
(1.94)\end{array}$ & $\begin{array}{c}0.324^{*} \\
(1.95)\end{array}$ \\
\hline$F^{*} \mathrm{RER}$ & & $\begin{array}{c}-0.013^{* *} \\
(-2.221)\end{array}$ & & $\begin{array}{l}-0.010^{*} \\
(-1.647)\end{array}$ & $\begin{array}{c}-0.090^{* * *} \\
(-2.628)\end{array}$ & & $\begin{array}{c}-0.088^{* * *} \\
(-2.586)\end{array}$ \\
\hline$B^{*}$ RER & & & $\begin{array}{c}-0.026^{* * *} \\
(-2.688)\end{array}$ & $\begin{array}{c}-0.021^{* *} \\
(-2.128)\end{array}$ & & $\begin{array}{c}-0.046^{* *} \\
(-2.109)\end{array}$ & $\begin{array}{c}-0.044^{* *} \\
(-2.027)\end{array}$ \\
\hline TFP*RER & & & & & $\begin{array}{c}-0.026 \\
(-1.610)\end{array}$ & $\begin{array}{c}-0.026 \\
(-1.584)\end{array}$ & $\begin{array}{c}-0.026 \\
(-1.600)\end{array}$ \\
\hline$F$ & & $\begin{array}{c}-0.003 \\
(-0.146)\end{array}$ & & $\begin{array}{c}-0.003 \\
(-0.160)\end{array}$ & $\begin{array}{c}-0.097 \\
(-0.697)\end{array}$ & & $\begin{array}{c}-0.102 \\
(-0.750)\end{array}$ \\
\hline$B$ & & & $\begin{array}{c}-0.014 \\
(-0.221)\end{array}$ & $\begin{array}{l}-0.012 \\
(-0.197)\end{array}$ & & $\begin{array}{l}0.227 \\
(0.88)\end{array}$ & $\begin{array}{l}0.233 \\
(0.90)\end{array}$ \\
\hline TFP & & & & & $\begin{array}{l}0.062 \\
(0.88)\end{array}$ & $\begin{array}{c}0.06 \\
(0.84)\end{array}$ & $\begin{array}{l}0.063 \\
(0.89)\end{array}$ \\
\hline profitr & & & & & $\begin{array}{c}0.382^{* * *} \\
(4.52)\end{array}$ & $\begin{array}{c}0.385^{* * *} \\
(4.55)\end{array}$ & $\begin{array}{c}0.384^{* * *} \\
(4.52)\end{array}$ \\
\hline$R \& D$ & & & & & $\begin{array}{c}0.026^{* *} \\
(2.34)\end{array}$ & $\begin{array}{c}0.026^{* *} \\
(2.39)\end{array}$ & $\begin{array}{c}0.026^{* *} \\
(2.37)\end{array}$ \\
\hline$N$ & $2,683,935$ & $1,334,937$ & $1,334,937$ & $1,334,937$ & 125,253 & 125,253 & 125,253 \\
\hline$R^{2}$ & 0.3228 & 0.3663 & 0.3663 & 0.3663 & 0.3788 & 0.3788 & 0.3788 \\
\hline
\end{tabular}

Note: the $t$-statistic value of the variable is placed in parenthesis. ${ }^{*} p<0.10,{ }^{* *} p<0.05$, and ${ }^{* * *} p<0.01$.

linkages at the same time after controlling for the TFP channel and other control variables. It shows that the coefficient on the interaction term is significant and negative for both the single channel and the dual channel, indicating that the exchange rate risk is still weakened for firms through the joint effects of the "hedging effect" and the "comovement effect." The coefficient on the interaction of TFP and the exchange rate is negative, indicating that the higher the firm's TFP is, the smaller the trade elasticity is and the less exchange rate risk is faced by the firms. This finding is consistent with existing research conclusions [7, 17]. The firm profit rate and R\&D both have significant positive effects on exports, indicating that an increase in the profit rate and $R \& D$ investment will increase firms' exports. The above results show that after controlling for the TFP channel and other control variables, GVC forward linkages and backward linkages are still significant and exchange rate risk is still weakened for firms through the "hedging effect" and the "comovement effect" in the GVC. Thus, the main conclusion of this paper still holds.

In conclusion, the weakening of the exchange rate risk is more significant after firms participate in the GVC. This is because after firms participate in the GVC, both the "comovement effect" for forward linkages and the "hedge effect" for backward linkages significantly reduce the exchange rate risk. Reasonable suggestion that firms participate in the GVC will be an effective way of avoiding the exchange rate risk.

\subsection{Robustness}

4.2.1. Alternative Measurement of Forward and Backward Linkages. To ensure that our empirical results are still robust when different measurement methods are used for GVC forward linkages and GVC backward linkages, the first column of Table 5 shows the regression results when using the virtual variable values of GVC forward linkages and GVC backward linkages. The upstreamness of a firm can be divided into three levels: high, middle, and low. The values of $-1,0$, and 1 are taken as the virtual substitution variables for these levels, and the standardized downstreamness is taken as its virtual substitution variable. Both variables are introduced into the regression equation simultaneously. From the results, although the significance of the coefficient has changed, the direction of the coefficient is consistent with the previous conclusion, that is, the greater the GVC forward or backward linkages, the more the exchange rate risk weakens.

4.3. Sample Selection. Before China's exchange rate reform in 2005, the RMB was fixed to the United States (US) dollar, and fluctuation of the real exchange rate was mainly due to CPI fluctuation from the two countries rather than nominal exchange rate fluctuation. To reflect the impact of nominal exchange rate fluctuation risk on exports, subsamples after the exchange rate reform in 2005 were used to test the robustness of the results. During this period, the bilateral real exchange rate risk reflected both bilateral nominal exchange rate fluctuation and bilateral CPI fluctuation. The results in the second column of Table 5 show that the greater the forward or backward linkages of the GVC, the more the exchange rate risk weakens.

\subsection{Heterogeneity Analysis of GVC and Exchange Rate Risk}

4.4.1. Firm Size Heterogeneity. Firms are divided into two groups according to their scale of production: small-size firms and large-size firms. The results of column 1 and 2 in Table 6 show that as the scale of firms increases, the GVC's effect on weakening exchange rate risk gradually increases significantly. The "comovement effect" in GVC forward 
TABLe 5: Robustness test.

\begin{tabular}{|c|c|c|}
\hline & Alternative measures (1) & After 2005 (2) \\
\hline RER & $\begin{array}{c}0.342^{* *} \\
(2.051)\end{array}$ & $\begin{array}{c}0.257 \\
(1.415)\end{array}$ \\
\hline$F^{*} \mathrm{RER}$ & $\begin{array}{c}-0.034^{* * *} \\
(-5.621)\end{array}$ & $\begin{array}{c}-0.075^{* *} \\
(-2.001)\end{array}$ \\
\hline$B^{*} \mathrm{RER}$ & $\begin{array}{l}-0.002^{*} \\
(-1.665)\end{array}$ & $\begin{array}{c}-0.047^{* *} \\
(-2.068)\end{array}$ \\
\hline TFP*RER & $\begin{array}{c}-0.024 \\
(-1.538)\end{array}$ & $\begin{array}{c}-0.016 \\
(-0.967)\end{array}$ \\
\hline$F$ & $\begin{array}{c}-0.01 \\
(-0.255)\end{array}$ & $\begin{array}{c}-0.06 \\
(-0.316)\end{array}$ \\
\hline$B$ & $\begin{array}{c}0.015 \\
(0.896)\end{array}$ & $\begin{array}{c}0.101 \\
(0.372)\end{array}$ \\
\hline TFP & $\begin{array}{c}0.06 \\
(0.847)\end{array}$ & $\begin{array}{c}0.086 \\
(1.080)\end{array}$ \\
\hline profitr & $\begin{array}{c}0.385^{* * *} \\
(4.534)\end{array}$ & $\begin{array}{c}0.403^{* * *} \\
(3.771)\end{array}$ \\
\hline $\mathrm{R} \& \mathrm{D}$ & $\begin{array}{c}0.026^{* *} \\
(2.369)\end{array}$ & $\begin{array}{c}0.024^{* *} \\
(2.182)\end{array}$ \\
\hline $\begin{array}{l}N \\
R^{2}\end{array}$ & $\begin{array}{c}125,253 \\
0.3791\end{array}$ & $\begin{array}{c}112,556 \\
0.3831\end{array}$ \\
\hline
\end{tabular}

Note: the $t$-statistic value of the variable is in parenthesis. ${ }^{*} p<0.10,{ }^{* *} p<0.05$, and ${ }^{* * *} p<0.01$.

TABLE 6: Heterogeneity analysis of GVC and exchange rate risk.

\begin{tabular}{|c|c|c|c|c|c|c|}
\hline & Small size & Large size & Low income & High income & Foreign & Nonforeign \\
\hline RER & $\begin{array}{c}0.031 \\
(0.125)\end{array}$ & $\begin{array}{c}0.427^{* *} \\
(1.969)\end{array}$ & $\begin{array}{c}0.078 \\
(0.334)\end{array}$ & $\begin{array}{l}0.485^{* *} \\
(2.102)\end{array}$ & $\begin{array}{c}0.02 \\
(0.027)\end{array}$ & $\begin{array}{l}0.373^{* *} \\
(2.174)\end{array}$ \\
\hline$F^{*} \mathrm{RER}$ & $\begin{array}{c}-0.048 \\
(-1.168)\end{array}$ & $\begin{array}{c}-0.125^{* *} \\
(-2.372)\end{array}$ & $\begin{array}{c}-0.022 \\
(-0.560)\end{array}$ & $\begin{array}{c}-0.120^{* *} \\
(-2.129)\end{array}$ & $\begin{array}{c}-0.531^{* * *} \\
(-3.112)\end{array}$ & $\begin{array}{c}-0.079^{* *} \\
(-2.318)\end{array}$ \\
\hline$B^{*} \mathrm{RER}$ & $\begin{array}{c}-0.012 \\
(-0.339)\end{array}$ & $\begin{array}{l}-0.061^{* *} \\
(-2.127)\end{array}$ & $\begin{array}{c}-0.011 \\
(-0.429)\end{array}$ & $\begin{array}{c}-0.079^{* *} \\
(-2.127)\end{array}$ & $\begin{array}{c}-0.132 \\
(-1.318)\end{array}$ & $\begin{array}{l}-0.042^{*} \\
(-1.883)\end{array}$ \\
\hline TFP*RER & $\begin{array}{c}-0.017 \\
(-0.834)\end{array}$ & $\begin{array}{l}-0.038^{*} \\
(-1.657)\end{array}$ & $\begin{array}{c}-0.021 \\
(-1.095)\end{array}$ & $\begin{array}{c}-0.054^{* *} \\
(-2.262)\end{array}$ & $\begin{array}{c}0.046 \\
(0.831)\end{array}$ & $\begin{array}{l}-0.030^{*} \\
(-1.815)\end{array}$ \\
\hline$F$ & $\begin{array}{c}-0.244 \\
(-1.276)\end{array}$ & $\begin{array}{c}-0.035 \\
(-0.187)\end{array}$ & $\begin{array}{c}-0.148 \\
(-1.015)\end{array}$ & $\begin{array}{c}-0.031 \\
(-0.161)\end{array}$ & $\begin{array}{l}-1.366^{*} \\
(-1.876)\end{array}$ & $\begin{array}{c}-0.066 \\
(-0.494)\end{array}$ \\
\hline$B$ & $\begin{array}{c}-0.22 \\
(-0.723)\end{array}$ & $\begin{array}{c}0.307 \\
(0.863)\end{array}$ & $\begin{array}{c}0.252 \\
(0.751)\end{array}$ & $\begin{array}{c}0.299 \\
(1.012)\end{array}$ & $\begin{array}{c}0.644 \\
(0.636)\end{array}$ & $\begin{array}{c}0.209 \\
(0.787)\end{array}$ \\
\hline TFP & $\begin{array}{c}0.118 \\
(1.236)\end{array}$ & $\begin{array}{c}-0.044 \\
(-0.377)\end{array}$ & $\begin{array}{c}0.105 \\
(1.119)\end{array}$ & $\begin{array}{c}0.052 \\
(0.575)\end{array}$ & $\begin{array}{c}0.252 \\
(1.469)\end{array}$ & $\begin{array}{c}0.042 \\
(0.537)\end{array}$ \\
\hline profitr & $\begin{array}{c}0.413^{* * *} \\
(3.298)\end{array}$ & $\begin{array}{c}0.379^{* * *} \\
(3.345)\end{array}$ & $\begin{array}{l}0.275^{* *} \\
(2.080)\end{array}$ & $\begin{array}{c}0.448^{* * *} \\
(4.339)\end{array}$ & $\begin{array}{c}-0.099 \\
(-0.159)\end{array}$ & $\begin{array}{c}0.401^{* * *} \\
(4.668)\end{array}$ \\
\hline$R \& D$ & $\begin{array}{l}0.043^{* *} \\
(2.524)\end{array}$ & $\begin{array}{c}0.021 \\
(1.388)\end{array}$ & $\begin{array}{c}0.017 \\
(1.168)\end{array}$ & $\begin{array}{c}0.034^{* *} \\
(2.413)\end{array}$ & $\begin{array}{c}-0.025 \\
(-0.366)\end{array}$ & $\begin{array}{l}0.027^{* *} \\
(2.452)\end{array}$ \\
\hline$N$ & 48,079 & 77,061 & 47,743 & 75,806 & 4,193 & 121,038 \\
\hline$R^{2}$ & 0.3478 & 0.347 & 0.4308 & 0.427 & 0.4136 & 0.379 \\
\hline
\end{tabular}

Note: the $t$-statistic value of the variable is in parenthesis. ${ }^{*} p<0.10,{ }^{* *} p<0.05$, and ${ }^{* * *} p<0.01$.

linkages increases from 0.048 to 0.125 , and the "hedge effect" in GVC backward linkages increases from 0.012 to 0.061 . This finding is consistent with previous research [4]. Largesize firms generally import and export on a large scale, and so they are greatly influenced by GVC forward and backward linkages. As firm size increases, the GVC's role of weakening exchange rate risk becomes more prominent.

4.4.2. Export Destination Country Heterogeneity. Firms are divided into two groups according to the income level of export destination countries: exports to low-income countries and exports to high-income countries. The results in column 3 and 4 of Table 6 show that for an increase in the income level of export destination countries, the impact of the GVC on trade elasticity increases, with the "comovement effect" in GVC forward linkages increasing the coefficient from 0.022 to 0.120 and the "hedge effect" in GVC backward linkages increasing the coefficient from 0.011 to 0.079 . This shows that the GVC's role of weakening the exchange rate risk is more prominent when Chinese firms export to developed countries.

4.4.3. Firm Style Heterogeneity. Firms are divided into two groups: foreign firms and nonforeign firms according to whether they are characterized by foreign participation or 
not. It is generally accepted that foreign firm exports are, to a large extent, part of the interfirm trade. Thus, it can be argued that the export volume of foreign firms does not accurately reflect market prices, and this is why the exports show an insensitivity towards exchange rate risk. The results in columns 5 and 6 of Table 6 show that trade elasticity itself and GVC forward and backward linkages are not sensitive to their impact, which is consistent with our hypothesis.

\section{Conclusion}

With deepening participation in the GVC, the weakening of the exchange rate risk has become increasingly significant. This paper analyzes the relationship between participation in the GVC and the exchange rate risk from the perspectives of forward linkages and backward linkages. The main conclusions are as follows: firms with a high upstreamness have a larger "comovement effect" that buffers against some exchange rate risks; firms with higher downstreamness have a larger "hedging effect" that hedges against some exchange rate risks. Participation in the GVC reduces the exchange rate risk particularly for exports to high-income countries.

The conclusions of this paper have the following policy implications. Firstly, the GVC system strengthens the stability of exports when exposed to the exchange rate risk, and participation in the GVC can weaken the exchange rate risk. Within the context of the continuous accumulation of the exchange rate risk, advising firms to integrate into the GVC is an effective way to avoid the exchange rate risk. Secondly, from the perspective of reducing the exchange rate risk, encouraging firms to strengthen GVC ties with high-income countries will play an important role in minimizing the exchange rate risk.

\section{Data Availability}

The data used to support the findings of this study are available from the corresponding author upon request.

\section{Disclosure}

Any remaining errors in the paper are the responsibility of the authors.

\section{Conflicts of Interest}

The authors declare that they have no conflicts of interest.

\section{Acknowledgments}

The second author acknowledges the support from the Major Program of China's National Social Science (Grant no. 17ZDA040).

\section{References}

[1] A. Burstein and G. Gopinath, "International prices and exchange rates," in Handbook of International Economics, vol. 4, pp. 391-451, Elsevier, Amsterdam, Netherlands, 2014.
[2] R. C. Johnson and G. Noguera, "Accounting for intermediates: production sharing and trade in value added," Journal of International Economics, vol. 86, no. 2, pp. 224-236, 2012.

[3] J. M. Campa and L. S. Goldberg, "Exchange rate pass-through into import prices," Review of Economics and Statistics, vol. 87, no. 4, pp. 679-690, 2005.

[4] M. Amiti, O. Itskhoki, and J. Konings, "Importers, exporters, and exchange rate disconnect," American Economic Review, vol. 104, no. 7, pp. 1942-1978, 2014.

[5] S. Ahmed, "Are Chinese exports sensitive to changes in the exchange rate?" in International Finance Discussion Paper, Vol. 987, Federal Reserve Bank, Washington, DC, USA, 2009.

[6] D. Greenaway, A. Mahabir, and C. Milner, "Has China displaced other Asian countries' exports?" in China and the World Economy, pp. 60-90, Palgrave Macmillan, London, UK, 2010.

[7] N. Berman, P. Martin, and T. Mayer, "How do different exporters react to exchange rate changes?" The Quarterly Journal of Economics, vol. 127, no. 1, pp. 437-492, 2012.

[8] D. Fauceglia, A. Lassmann, A. Shingal, and M. Wermelinger, "Backward participation in global value chains and exchange rate driven adjustments of Swiss exports," Review of World Economics, vol. 154, no. 3, pp. 537-584, 2018.

[9] P. R. Bergin and R. C. Feenstra, "Pass-through of exchange rates and competition between floaters and fixers," Journal of Money, Credit and Banking, vol. 41, pp. 35-70, 2009.

[10] K. De Backer and N. Yamano, "International Comparative Evidence on Global Value Chains," Organisation for Economic Co-operation and Development, Paris, France, 2012.

[11] W. Powers and D. Riker, "Exchange rate pass-through in global value chains: the effects of upstream suppliers," in US International Trade Commission, Office of Economics Working Paper, Washington, DC, USA, 2013.

[12] P. Antràs and D. Chor, "On the measurement of upstreamness and downstreamness in global value chains," World Trade Evolution, vol. 32, no. 2, pp. 126-194, 2018.

[13] D. Chor, K. Manova, and Z. Yu, "The global production line position of Chinese firms," in Proceedings of the Industrial Upgrading and Urbanization Conference, vol. 28, p. 29, Stockholm, Sweden, August 2014.

[14] R. Upward, Z. Wang, and J. Zheng, "Weighing China's export basket: the domestic content and technology intensity of Chinese exports," Journal of Comparative Economics, vol. 41, no. 2, pp. 527-543, 2013.

[15] G. S. Olley and A. Pakes, "The dynamics of productivity in the telecommunications equipment industry," Econometrica, vol. 64, no. 6, pp. 1263-1297, 1996.

[16] A. Borin, V. Di Nino, M. Mancini, and M. Sbracia, "The cyclicality of the income elasticity of trade," in Temi Di Discussione (Working Paper), no. 1126, Bank of Italy, Rome, Italy, 2017.

[17] H. Li, H. Ma, and Y. Xu, "How do exchange rate movements affect Chinese exports?-a firm-level investigation," Journal of International Economics, vol. 97, no. 1, pp. 148-161, 2015. 